\title{
Zmiany zachowań rozrodczych w XXI wieku - czy program Rodzina 500+ ma na nie wpływ?
}

\section{Wprowadzenie}

W ostatnich latach przemiany demograficzne zachodzące w Polsce w ciągu minionego trzydziestolecia traktowane są jako źródło poważnych zagrożeń dla przyszłości naszego państwa. Dostrzega się nie tylko widoczny w prognozach wszystkich instytucji statystycznych - polskich i międzynarodowych - spadek liczby ludności, ale i przyspieszone starzenie się populacji, zmniejszanie liczby osób w wieku produkcyjnym oraz przestrzenne zróżnicowanie skali i tempa depopulacji. Wszystkie te przemiany - niezależnie od tego, czy dopiero są prognozowane, czy już obecne w naszym życiu wpływają na wyraźny wzrost zainteresowania decydentów różnego szczebla procesami demograficznymi, czyli na tzw. polityzację przemian demograficznych ${ }^{1}$. Jednym z przejawów owego zainteresowania jest wprowadzenie w 2016 roku rządowego programu Rodzina 500+.

\footnotetext{
${ }^{1}$ M. Duszczyk, M. Lesińska, Upolitycznienie procesów demograficznych - próba podejścia teoretycznego, „Problemy Polityki Społecznej” (2016), 3 (34), s. 13-25; http://www.problemypolitykispolecznej.pl/images/czasopisma/PELNE/PPSSiD34.pdf (dostęp: 13.08.2018).
} 
Program ten ma dwa główne cele 2 : pronatalistyczny i socjalny. W niniejszym opracowaniu skupię się jedynie na pierwszym z nich. W tym przypadku zamiarem rządu było choć częściowe wykorzystanie „rezerwy demograficznej”, a zatem tych osób w wieku zdolności prokreacyjnej, które deklarują występowanie przeszkód uniemożliwiających realizację planów rozrodczych ${ }^{3}$. Ci potencjalni rodzice, w przypadku których to kwestie materialne były powodem odstępstw od realizacji planów rozrodczych, wraz z dostępem do dodatkowych środków finansowych uzyskują większą możliwość osiągania własnych zamierzeń odnośnie do wielkości rodziny. Pisząc o spodziewanych skutkach wdrożonego instrumentu polityki rodzinnej, chciałbym podkreślić ich hipotetyczność. Nie mamy żadnych realnych przesłanek, aby oceniać skuteczność wdrażanych przez rząd rozwiązań dla obecnego i przyszłego rozwoju demograficznego Polski. Co więcej, trudno byłoby nawet w przypadku znajomości przyszłej liczby urodzeń wyodrębnić zmiany wynikające $\mathrm{z}$ wdrożenia programu Rodzina 500+ od zmian związanych $\mathrm{z}$ realizacją innych instrumentów polityki rodzinnej (urlopy macierzyńskie, rodzicielskie, ojcowskie; rozbudowa systemu opieki instytucjonalnej nad małym dzieckiem) czy wreszcie od poprawy sytuacji na rynku pracy (niższe bezrobocie, większa pewność pracy, lepsze warunki pracy, wyższe wynagrodzenia).

Celem niniejszego opracowania jest spojrzenie na przemiany zachodzące w latach 2016-2017 (przy czym głównie zajmować się będę rokiem 2017 jako tym, w którym możnaby się spodziewać pełnych efektów wdrożenia programu Rodzina 500+) w sferze prokreacji, a także próba dokonania ich interpretacji zgodnie z oczekiwaniami odnośnie do wpływu tegoż programu rządowego na wzrost liczby urodzeń.

2 A. Gromada, Rodzina 500+ jako polityka publiczna;http://krytykapolityczna.pl/ file/2016/02/gromada_rodzina_500.pdf (dostęp: 13.08.2018); D. Puślecki, Polityka wsparcia rodziny czy stymulowanie wzrostu demograficznego w Programie Rodzina 500 plus, „Przegląd Politologiczny" (2016), nr 3, s. 79-91;http://pressto.amu.edu.pl/index.php/pp/article/viewFile/7203/7230 (dostęp: 13.08.2018).

3 Kotowska I. (red.), Niska dzietność w Polsce w kontekście percepcji Polaków. Diagnoza społeczna 2013, Warszawa 2014, s. 73; http://www.diagnoza.com/pliki/raporty_tematyczne/Niska_dzietnosc_w_Polsce.pdf (dostęp: 13.08.2018). 


\section{Liczba urodzeń i dzietność}

W pierwszej kolejności przyjrzyjmy się zmianom liczby urodzeń oraz poziomu dzietności. Rok 2017 to pierwszy od 2010 rok, gdy na świat przyszło ponad 400 tys. dzieci, choć już w 2016 r. można było zaobserwować wyraźny wzrost w stosunku do roku poprzedniego (rys. 1), bowiem rok 2015 był okresem najniższej liczby urodzeń po 2005 roku.

Rysunek 1. Liczba urodzeń w Polsce w latach 1980-2017 (w tys.)

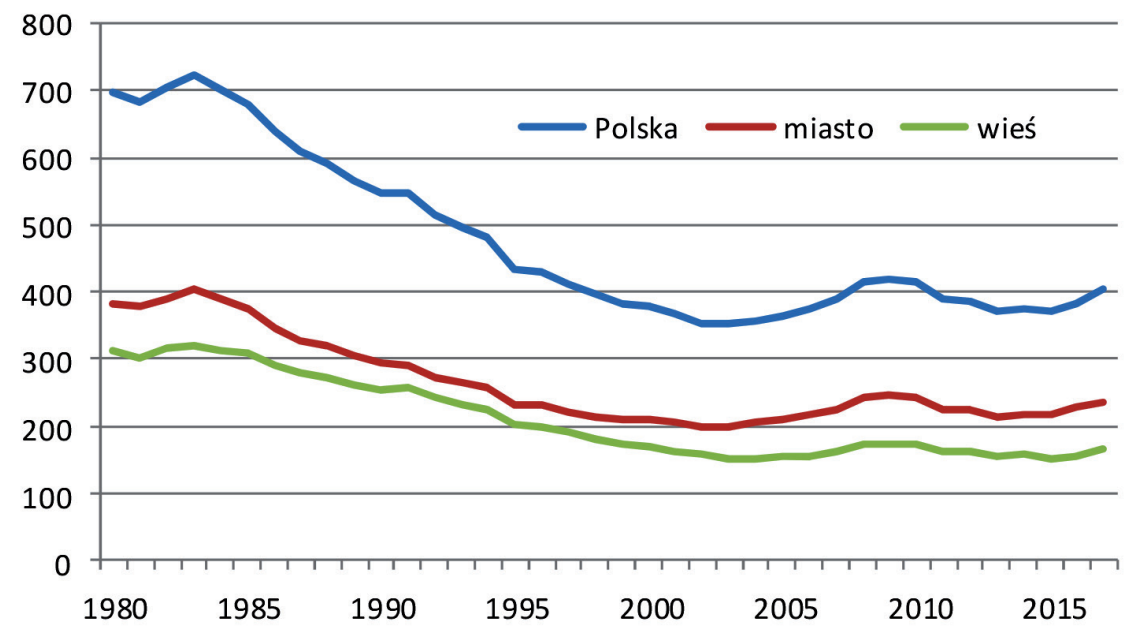

Źródło: Roczniki Demograficzne GUS oraz baza danych GUS Demografia.

Co więcej, stało się tak w warunkach zmniejszania się liczby kobiet w wieku rozrodczym, a zwłaszcza w wieku najwyższej płodności. Począwszy od 1983 do 2003 roku, corocznie następował spadek liczby urodzeń, w efekcie czego zmniejsza się też (z odpowiednim opóźnieniem) liczba młodych kobiet, które mogłyby zostać matkami. To dlatego owe 402 tys. urodzeń przełożyło się na niewidziany od 20 lat współczynnik dzietności równy 1,45 (ostatni raz wyższą wartość - 1,47 - odnotowano w 1997 roku). Współczynnik ten - zwany również współczynnikiem całkowitej płodności - mówi o tym, jaka byłaby przeciętna liczba potomstwa urodzonego przez typową kobietę $\mathrm{w}$ warunkach utrzymywania się częstości wydawania dzieci na świat odnotowanego w danym roku. Choć - jak wspomniano - poziom 
współczynnika dzietności równy 1,45 dziecka na kobietę nie był w Polsce notowany od wielu lat (rys. 2), to wciąż jest to wartość niska, albowiem zapewnienie prostej zastępowalności pokoleń wymaga osiągnięcia wartości bliskiej 2,1 (ok. 2,06-2,07). Wartość ta zakłada nie tylko urodzenie dzieci w liczbie zastępującej rodziców, ale również zrekompensowanie umieralności części dzieci przed rozpoczęciem prokreacji oraz odpowiednią relację między liczbą kobiet i mężczyzn.

Rysunek 2.Współczynniki dzietności w Polsce w latach 1980-2017

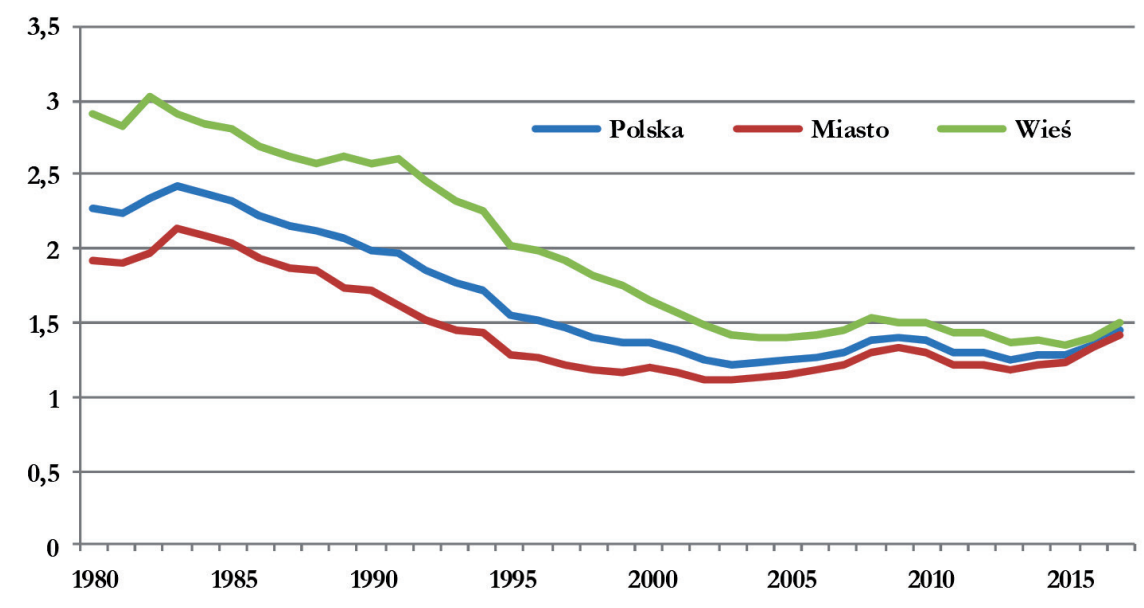

Źródło: Roczniki Demograficzne GUS oraz baza danych GUS Demografia.

Patrząc na zachodzące w latach 2016-2017 zmiany liczby urodzeń i współczynnika dzietności, można powiedzieć o znacznym wzroście liczby urodzeń (w stosunku do 2015 w roku 2017 urodziło się o 8,9\% więcej dzieci). Jednocześnie warto zaznaczyć, że urodziło się znacznie więcej dzieci, niż wynikało to z prognozy GUS z 2014 roku, choć trzeba powiedzieć, iż od samego momentu jej opublikowania pojawiały się duże i narastające z czasem niedoszacowania liczby urodzeń (tab. 1). 
Tabela 1. Liczba urodzeń rzeczywista i prognozowana przez GUS zgodnie z prognozą z 2014 r. (w tys. osób)

\begin{tabular}{|l|c|c|c|}
\hline Rok & $\begin{array}{c}\text { Liczba } \\
\text { prognozowana }\end{array}$ & $\begin{array}{c}\text { Liczba } \\
\text { rzeczywista }\end{array}$ & $\begin{array}{c}\text { Liczba rzeczywista jako \% liczby } \\
\text { prognozowanej (w \%) }\end{array}$ \\
\hline 2014 & 360,4 & 375,2 & 104,1 \\
\hline 2015 & 353,9 & 369,3 & 104,3 \\
\hline 2016 & 348,8 & 382,3 & 109,6 \\
\hline 2017 & 345,9 & 402,0 & 116,2 \\
\hline
\end{tabular}

Źródło: Baza danych GUS Demografia, Prognoza ludności na lata 2014-2050 i obliczenia własne.

Wskazuje to, iż prawdopodobnie i bez wdrażania rządowych bodźców liczba urodzeń byłaby wyższa - choć może w mniejszej skali od tej zaobserwowanej w rzeczywistości - od liczby wynikającej z wariantu podstawowego prognozy GUS z 2014 roku. Rząd zakładał, iż poprawa warunków bytowych rodzin powinna zaowocować podwyższeniem się skłonności do posiadania potomstwa $\mathrm{z}$ wariantu wysokiego założeń odnośnie do rozrodczości przyjętego w upublicznionej pod koniec 2014 roku prognozy na wariant bardzo wysoki ${ }^{4}$. W rzeczywistości osiągnięte rezultaty były lepsze od tych zakładanych; wariant bardzo wysoki zakładał urodzenie się 376,6 tys. dzieci w 2016 i 378,2 tys. w 2017 roku, w rzeczywistości zaś liczba urodzeń była wyższa odpowiednio o 5,7 i 23,8 tys.

\section{Płodność}

W dalszej kolejności przyjrzymy się zmianom płodności. Płodność oznacza natężenie urodzeń w zbiorowości kobiet w wieku rozrodczym (zazwyczaj w przeliczeniu na 1000 kobiet w danym wieku), zaś analiza tzw. cząstkowych współczynników płodności obliczanych dla jednorodnych grup wieku pozwala na sprawdzenie, czy i w jakim stopniu zmienia się gotowość do wydawania potomstwa według wieku.

\footnotetext{
${ }^{4}$ Zob. dane w ocenie skutków regulacji ustawy wprowadzającej program Rodzina 500+; https://legislacja.rcl.gov.pl/docs//2/12279566/12326797/12326798/dokument202546.pdf (dostęp: 13.08.2018).
} 
W trakcie ostatnich trzech dekad występowały duże zmiany, jeśli idzie o rozkład współczynników płodności według wieku. Wskazują one na coraz mniejszą - choć w zróżnicowany sposób w zależności od wieku - gotowość do wydawania na świat dzieci oraz generalnie odraczanie decyzji prokreacyjnych, tj. przesuwanie ich na późniejszą fazę życia (rys. 3).

Rysunek 3. Rozkład cząstkowych współczynników płodności w latach 1990-2017

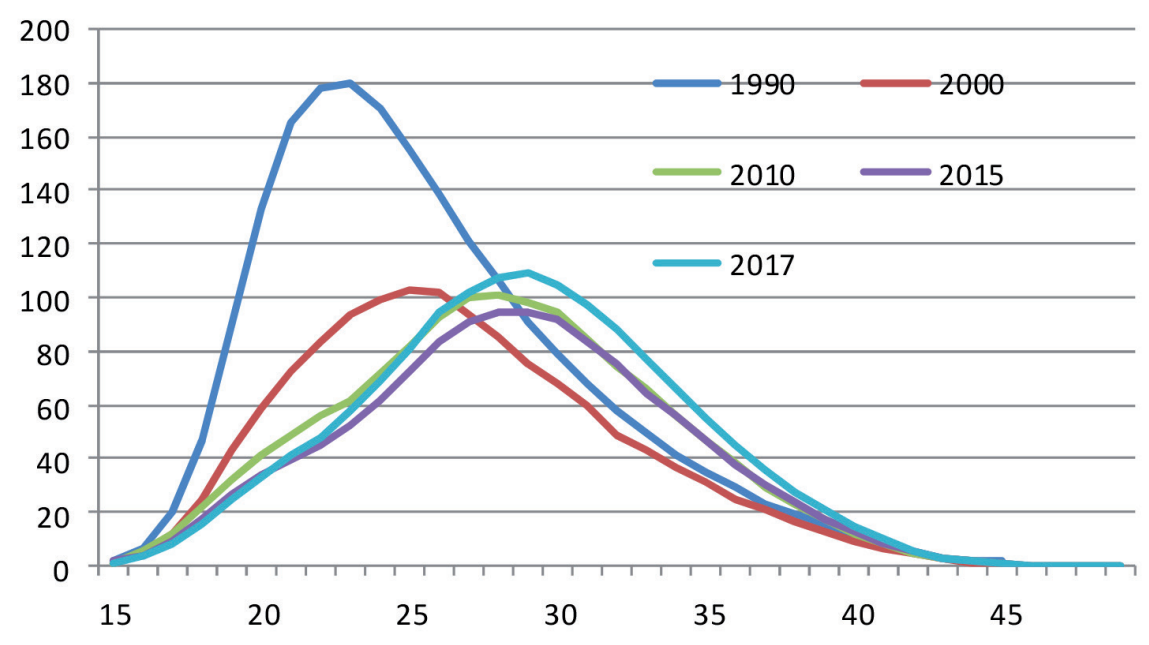

Źródło: Roczniki Demograficzne GUS oraz baza danych GUS Demografia.

Ostatnie dwa lata przyniosły pod tym względem zmianę, albowiem jak już wiemy - generalnie podniósł się poziom dzietności, a zatem musiał podnieść się i poziom płodności, którego jest sumą. Nie dotyczyło to jednak każdego wieku, albowiem - niezależnie od miejsca zamieszkiwania - wśród kobiet bardzo młodych między rokiem 2015 a 2017 płodność zmniejszyła się (rys. 4). Wskazuje to na zmieniające się, a silnie zakorzenione, społeczne oczekiwania odnośnie do najlepszego wieku, w którym należy zostać matką (rodzicem). 
Rysunek 4. Zmiany cząstkowych współczynników płodności według wieku w latach 2015-2017 w podziale na miasto i wieś
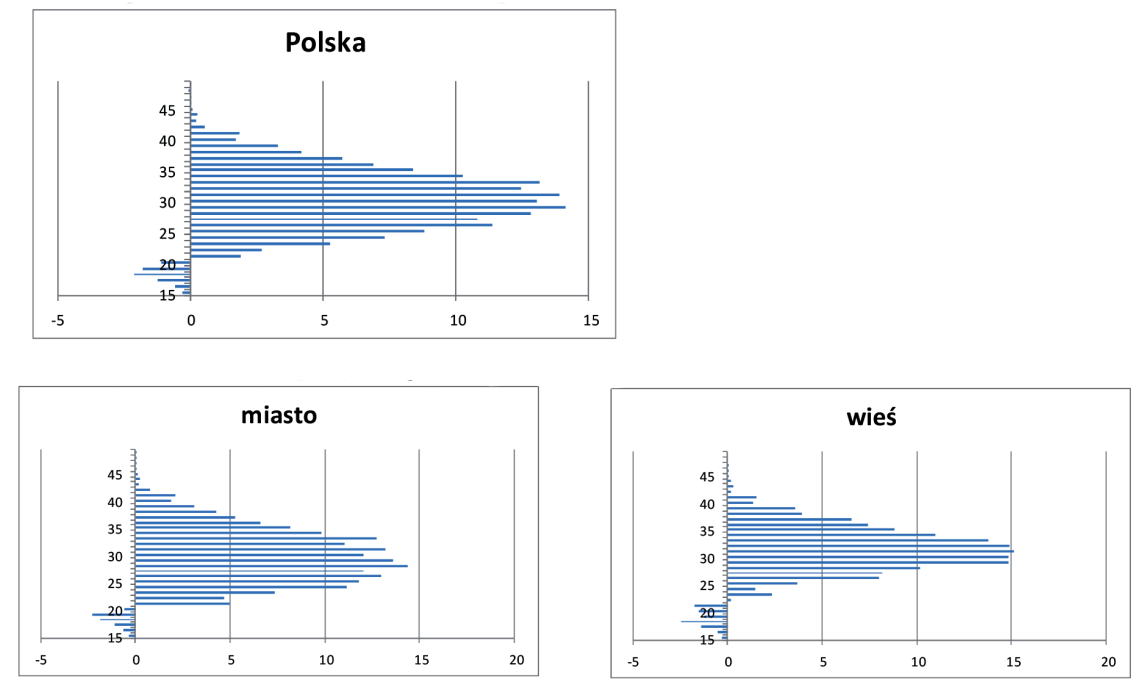

Źródło: Obliczenia własne na podstawie bazy danych GUS Demografia.

Między mieszkankami miast i wsi występowała jednak pewna różnica. U tych drugich maksymalny przyrost współczynników płodności wystąpił wśród kobiet w wieku 29-33 lata, podczas gdy u mieszkanek miast grupa wieku silnie dotknięta wzrostem płodności była znacznie większa: 25-34 lata.

\section{Urodzenia i płodność według kolejności}

Niska liczba urodzeń i niska płodność w minionych kilkunastu latach wynikały przede wszystkim z niskiej skłonności do wydawania na świat dzieci wyższej kolejności. Przez długi czas dzieci pierwsze odpowiadały za połowę - lub nawet więcej - urodzeń. Lata 2016-2017 przyniosły wyraźne zmniejszenie się odsetka urodzeń niskiej rangi (rys. 5). Proces ten, choć rozpoczęty w roku 2005, bardzo wyraźnie przyspieszył w okresie wdrażania programu Rodzina 500+. Po części proces ten jest naturalną konsekwencją zmiany struktury kobiet w wieku rozrodczym - ich największa liczba znajduje się w wieku ok. 35 lat, a zatem wówczas gdy wydaje się na świat nie pierwsze dziecko, ale z reguły już te kolejne. 
Rysunek 5. Urodzenia według kolejności w latach 1988-2017 (jako \% ogółu urodzeń)

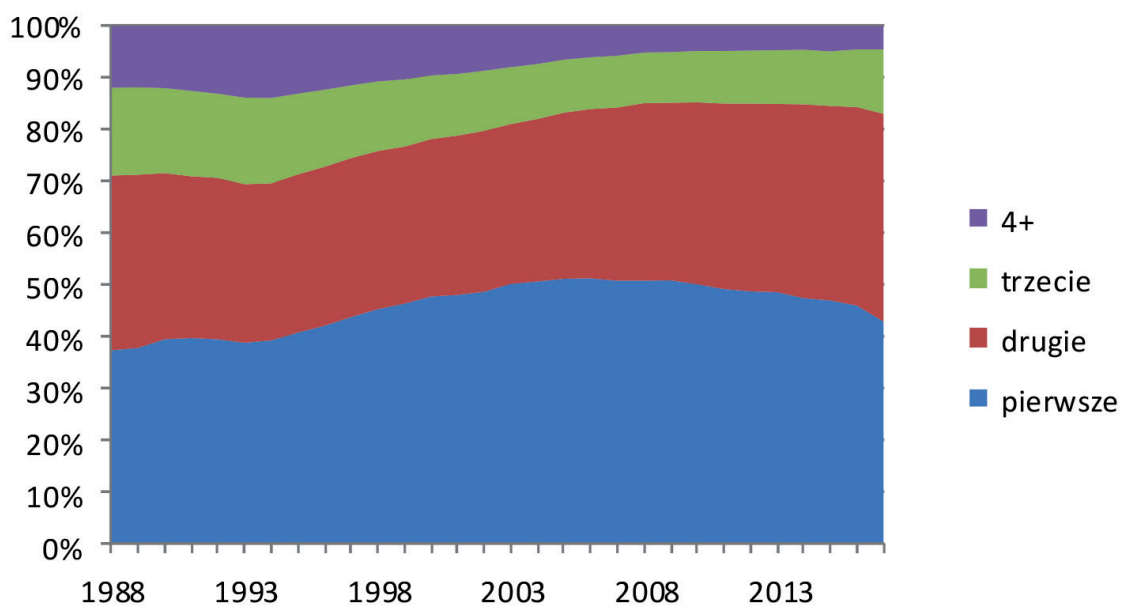

Źródło: Roczniki Demograficzne GUS oraz baza danych GUS Demografia.

Rysunek 6. Płodność według kolejności urodzeń w latach 1990-2017 (urodzenia danej kolejności na 1000 kobiet w danym wieku)

1990

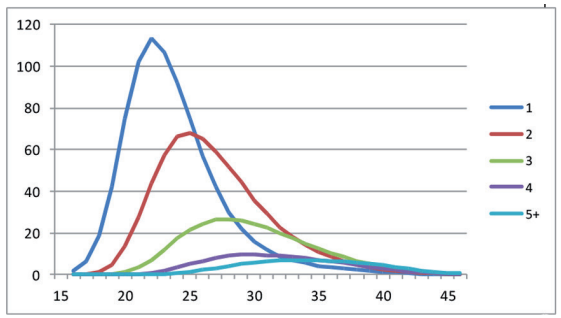

2015

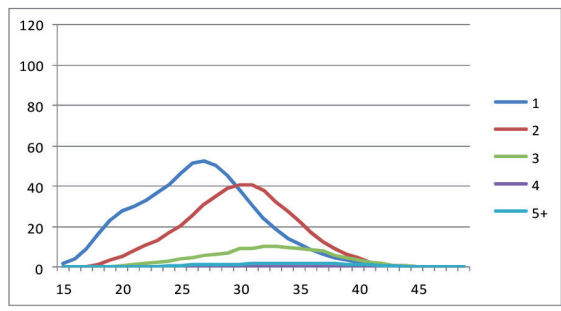

2010

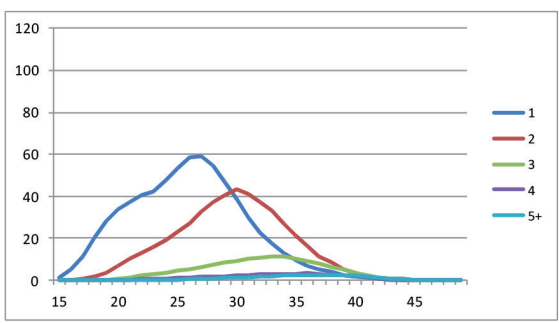

2017

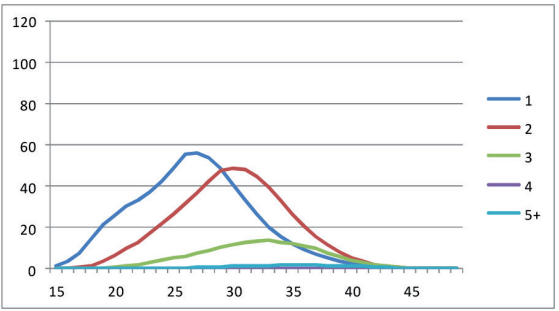

Źródło: Obliczenia własne na podstawie Roczników Demograficznych GUS oraz bazy danych GUS Demografia. 
Stąd też zdecydowanie poprawniejszym sposobem analizy danych na temat zachodzących zmian jest sprawdzenie, jak zmieniała się w ostatnich latach płodność według kolejności. Termin płodność, jak już wiemy, oznacza natężenie urodzeń $\mathrm{w}$ zbiorowości kobiet $\mathrm{w}$ wieku rozrodczym w przeliczeniu na 1000 kobiet w danym wieku. W tym przypadku będziemy dodatkowo różnicować poziom płodności w zależności od kolejności urodzenia (rys. 6). Generalnie w dłuższym okresie następowało, z jednej strony, zmniejszanie się natężenia urodzeń pierwszych, drugich, a zwłaszcza tych dalszej kolejności, z drugiej zaś opóźnianie decyzji prokreacyjnych, przejawiające się przede wszystkim w występowaniu maksimum płodności w wyższym wieku.

Porównując rozkłady płodności dla lat 2015 i 2017, teoretycznie nie dostrzega się znaczących zmian. Są one jednak zdecydowanie bardziej zauważalne, jeśli dokonamy bardziej przemawiającego do wyobraźni zestawienia, wskazującego na przeobrażenia, jakie w tym okresie zaszły (rys. 7).

Rysunek 7. Zmiana cząstkowych współczynników płodności ze względu na kolejność urodzenia w latach 2015-2017 (w przeliczeniu na 1000 kobiet w danym wieku)

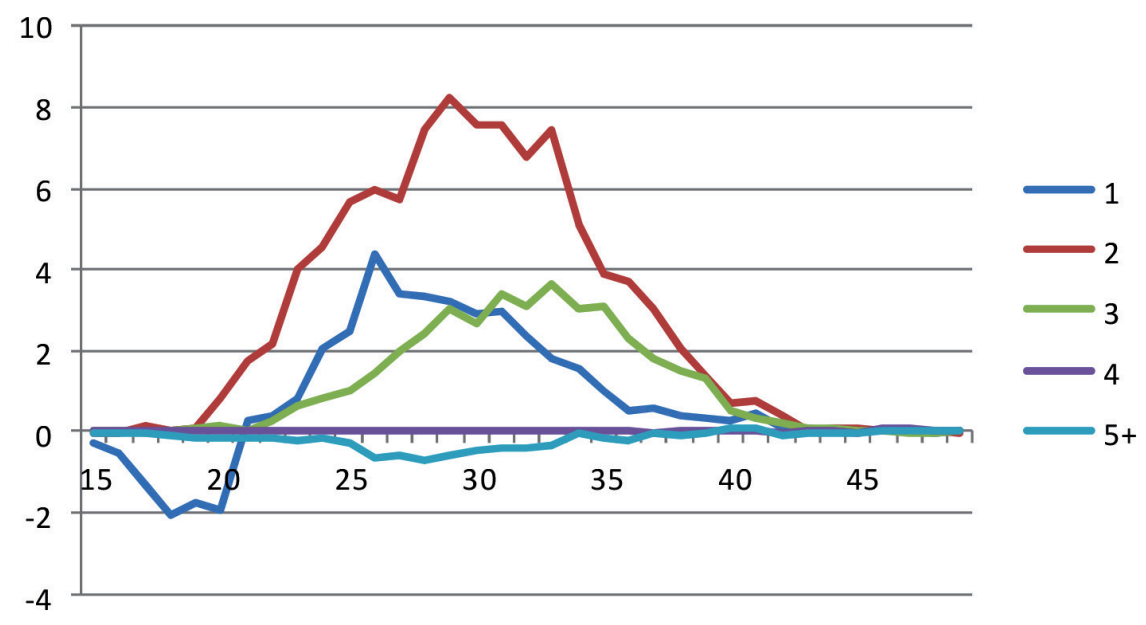

Źródło: Obliczenia własne na podstawie bazy danych GUS Demografia.

W takim przypadku widać, że największy przyrost płodności odnosił się do urodzeń drugich, a w następnej kolejności trzecich, w przypadku których widoczny jest przyrost - lub co najmniej stabilizacja - niezależnie od 
wieku matki. Tymczasem w przypadku płodności związanej z wydaniem na świat pierwszego dziecka, choć również odnotowano tu wzrost zauważalny zwłaszcza między 25. a 30. rokiem życia, zaobserwować można również wyraźny spadek płodności wśród nastolatek. A zatem występujące między 2015 a 2017 zmiany dotknęły szczególnie dzieci drugie i trzecie, przyczyniając się do znacznego wzrostu prawdopodobieństwa ich wydania na świat. W przypadku urodzeń wyższej rangi nie było oznak podniesienia płodności, a w przypadku urodzeń piątych i dalszych wręcz następował dalszy spadek prawdopodobieństwa wydawania takich dzieci na świat przez Polki $\mathrm{w}$ wieku rozrodczym.

\section{Wielodzietność 5}

Przedstawione powyżej zmiany były powiązane z częstością występowania wielodzietności. Termin ten kojarzy się we współczesnej Polsce nie najlepiej - w najlepszym przypadku z ubóstwem i niemożnością zapewnienia dzieciom odpowiedniego poziomu wykształcenia, zaś w najgorszym z patologią. Tymczasem z punktu widzenia zastępowalności pokoleń, wymagającej tego, aby typowa kobieta urodziła w trakcie swego życia nieco ponad dwoje dzieci $(2,1)$, w sytuacji gdy część kobiet nie może albo nie chce mieć dzieci, wielodzietność jest jedynym rozwiązaniem umożliwiającym zbliżenie się do reprodukcji prostej. Nie dziwi zatem zainteresowanie demografów tym zjawiskiem, którego skala i „głębokość” (tj. częstość wydawania dzieci dalszych kolejności) ma bezpośredni wpływ na długookresową sytuację ludnościową danego obszaru.

Sama kategoria wielodzietności zmieniała się w Polsce wraz ze zmianą modelu rodziny. Do drugiej wojny światowej oznaczała posiadanie przynajmniej pięciorga dzieci, w pierwszych powojennych dekadach - czworga i więcej, zaś od końca lat sześćdziesiątych do grona rodzin wielodzietnych zaliczane są w Polsce - podobnie jak w innych krajach rozwiniętych - te posiadające troje i więcej dzieci. Powyższa zmiana współwystępowała

\footnotetext{
${ }^{5} \mathrm{~W}$ niniejszym punkcie wykorzystuję zmodyfikowane i zaktualizowane fragmenty innego opracowania: P. Szukalski, Wielodzietność we współczesnej Polsce w świetle statystyk urodzeń, „Demografia i Gerontologia Społeczna - Biuletyn Informacyjny” (2018) nr 3, s. 1-6; http://hdl.handle.net/11089/24923 (dostęp: 13.08.2018).
} 
ze zmniejszaniem się częstości wydawania na świat dzieci wyższych rang (tj. dalszej kolejności). Przykładowo, o ile w okresie bezpośrednio powojennym odsetek dzieci czwartych i dalszych wynosił $20 \%$, o tyle w ostatnich latach równy jest jedynie 4-5\%, a jeśli trzymać się uznania za wielodzietność wydania na świat dzieci przynajmniej trzecich, to w roku 1950 sytuacja taka odnosiła się do 38\%, a obecnie (2017 r.) do 17\% urodzeń (rys. 5).

W skali kraju widoczne było w ostatnim ćwierćwieczu wyraźne zmniejszenie się liczby urodzeń wysokiej rangi, tym wyraźniejsze, im wyższej kolejności dzieci dotyczyło (tab. 2). Postępująca w okresie transformacji systemowej i później zmiana modelu rodziny przejawiała się - oprócz odraczania momentu stania się rodzicem - ograniczaniem dzietności. Ta ostatnia tendencja umacniana była przez wspomniane podwyższanie się wieku rodziców - część planowanych dzieci, zwłaszcza w przypadku wyższej rangi, nie została wydana na świat $z$ uwagi na związane $z$ wyższym wiekiem problemy zdrowotne obniżające szanse poczęcia i donoszenia płodu.

Tabela 2.Urodzenia ogółem i według kolejności w latach 1990-2017

\begin{tabular}{|c|c|c|c|c|c|c|c|c|}
\hline $\begin{array}{l}\text { Urodzenia } \\
\text { według } \\
\text { kolejności }\end{array}$ & 1990 & 1995 & 2000 & 2005 & 2010 & 2015 & 2016 & 2017 \\
\hline Trzecie & 89560 & 68127 & 46822 & 37555 & 41305 & 39039 & 42524 & 49965 \\
\hline Czwarte & 36530 & 30806 & 19050 & 12970 & 12090 & 9995 & 10735 & 11896 \\
\hline Piąte & 15258 & 13571 & 8484 & 5435 & 4304 & 3244 & 3589 & 3780 \\
\hline Szóste & 6747 & 6456 & 4388 & 2536 & 1816 & 1274 & 1353 & 1387 \\
\hline Siódme & 3240 & 3010 & 2103 & 1322 & 921 & 570 & 607 & 553 \\
\hline Ósme & \multirow{3}{*}{3651} & \multirow{3}{*}{3194} & \multirow{3}{*}{2398} & 692 & 417 & 282 & 254 & 246 \\
\hline Dziewiąte & & & & 356 & 227 & 124 & 123 & 127 \\
\hline $\begin{array}{l}\text { dziesiąte } \\
\text { i dalsze }\end{array}$ & & & & 449 & 261 & 102 & 111 & 100 \\
\hline $\begin{array}{l}\text { Urodzenia } \\
\text { ogółem }\end{array}$ & 545817 & 436312 & 380476 & 366095 & 415030 & 369308 & 382257 & 401982 \\
\hline
\end{tabular}

Źródło: Roczniki Demograficzne i Baza danych GUS Demografia; http://demografia.stat.gov. $\mathrm{pl} /$ bazademografia/Tables.aspx.

Ostatnie lata w przypadku urodzeń trzecich, czwartych - a w mniejszym stopniu i tych nieco wyższej kolejności - przynoszą powolny wzrost ich liczby. Nie należy tego traktować jako wskazówki mówiącej o powrocie do tra- 
dycyjnego modelu rodziny wielodzietnej, ale przede wszystkim jako efekt czynnika kohortowego, tj. dochodzenia do wieku odpowiedniego do wydawania dzieci wyższej rangi przez matki urodzone w trakcie tzw. drugiego powojennego wyżu demograficznego (przełom lat 70. i 80). Istnieje bowiem ścisły związek pomiędzy wiekiem nowo rodzących matek a kolejnością urodzenia. Wszak do wydania np. piątego dziecka niezbędne jest wcześniejsze urodzenie czworga, co - pomijając urodzenia wielorakie - wymaga dla każdego kolejnego dziecka czasu związanego z poczęciem, donoszeniem ciąży i przejściem przez okres pourodzeniowy, charakteryzujący się obniżonym prawdopodobieństwem zajścia w ciążę.

Ostatnie dwa lata bardzo wyraźnie wzmocniły wspomnianą tendencję, zwłaszcza w przypadku urodzeń trzecich. Realistycznie trzeba powiedzieć, iż urodzenia wyższej niż trzecie kolejności stanowią margines urodzeń ogółem (4,5\% w 2017 r.) i to margines zmniejszający się również w trakcie ostatnich dwóch lat. Przyrost dzietności dokonał się - jak już wiemy - głównie dzięki wzrostowi skłonności do posiadania drugiego i trzeciego dziecka. Jednakże wskutek wzrostu urodzeń trzecich skala wielodzietności ogółem wyraźnie wzrosła.

\section{Urodzenia pozamałżeńskie ${ }^{6}$}

Ostatnie dwa lata przyniosły również znaczne zmiany, jeśli idzie o urodzenia pozamałżeńskie. Generalnie, ostatnie trzydziestolecie to w Polsce czas trwałego i znacznego wzrostu udziału urodzeń pozamałżeńskich, które w miejsce $5 \%$ ogółu urodzeń z połowy lat 80 . odpowiadały w 2016 roku po raz pierwszy za $1 / 4$ urodzeń. Choć w trakcie tych lat pojawiały się krótkie okresy zahamowania przyrostu, to rok 2017 przyniósł całkowicie nowe, nieobserwowane w trakcie ostatnich trzydziestu lat zjawisko - spadek interesującego nas udziału. Po raz pierwszy w całym (po)transformacyjnym okresie wskaźnik urodzeń pozamałżeńskich spadł i to znacząco: z 25,0\% w $2016 \mathrm{r}$. do $24,1 \%$ w 2017 (w miastach z $27,7 \%$ do $27,2 \%$, zaś na wsi z $21,9 \%$ do 19,7\%) (rys. 8).

\footnotetext{
${ }^{6} \mathrm{~W}$ niniejszym punkcie wykorzystuję zmodyfikowane i zaktualizowane fragmenty innego opracowania: P. Szukalski, Dlaczego w 2017 r. nastapił spadek udziału urodzeń pozamałżeńskich?, „Demografia i Gerontologia Społeczna - Biuletyn Informacyjny” (2018) nr 5, s. 1-7; http://hdl.handle.net/11089/25395 (13.08.2018).
} 
Celem niniejszego punktu jest wskazanie przyczyn demograficznych takiej zmiany. Jak można domniemywać, zaobserwowana, a łączona z wprowadzeniem programu Rodzina 500+, zwiększona liczba urodzeń i wyższa dzietność mogą samoistnie wpływać na zmianę struktury urodzeń według statusu prawnego matek. Będzie tak, jeśli skłonność do wydawania na świat potomstwa stanie się silniejsza w populacji kobiet zamężnych niż tych niepozostających w formalnych związkach. Tak stało się i w Polsce, o czym pośrednio świadczyfakt, iż choć w roku 2017 odnotowano rekordowo wysoką liczbę urodzeń pozamałżeńskich (96,9 tys. wobec wcześniejszego rekordu z 2016 r. - 95,6 tys.), to przyrost liczby urodzeń małżeńskich był znacznie wyższy (305,1 tys. wobec 286,7 tys. w 2016 r.).

Rysunek 8.Udział urodzeń pozamałżeńskich wśród ogółu urodzeń w latach 1980-2017

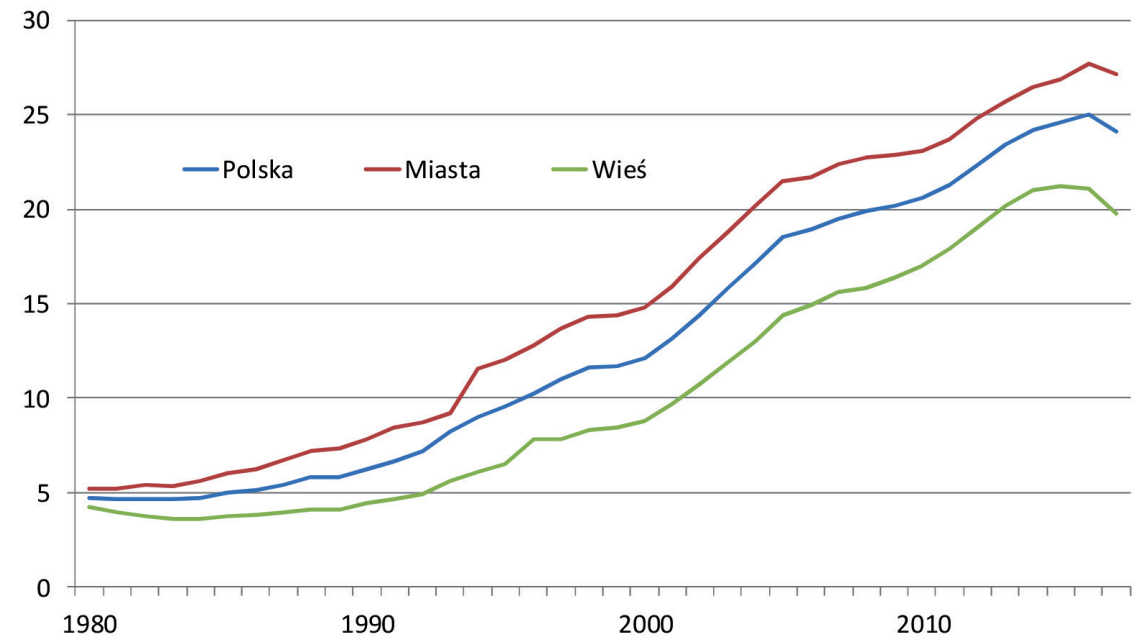

Źródło: Roczniki Demograficzne GUS i baza danych GUS Demografia.

Co się zatem stało? Wyjaśnienia należy szukać w bardziej szczegółowych informacjach na temat zachodzących zmian.

W pierwszej kolejności trzeba sobie zdawać sprawę ze ścisłego związku pomiędzy częstością urodzeń pozamałżeńskich a wiekiem matki ${ }^{7}$. Relacja ta ma związek krzywoliniowy - zdecydowana większość nastolatek we

${ }^{7}$ P. Szukalski, Urodzenia pozamałżeńskie w Polsce przełomu XX i XXI wieku, „Wiadomości Statystyczne” (2010) nr 2, s. 38-52; http://dspace.uni.lodz.pl:8080/xmlui/handle/11089/ 3636 (dostęp: 13.08.2018). 
współczesnej Polsce rodzi dzieci nieślubne (w przypadku kobiet mających mniej niż 16 lat nie ma skądinąd innej prawnej możliwości), potem szybko ów udział obniża się, wraz z przechodzeniem do kolejnych grup wieku, osiągając minimum ok. 30-35 lat, po czym powoli rośnie z wiekiem (zob. tab. 3). W takiej sytuacji najprostszym wyjaśnieniem byłoby stwierdzenie, iż generalnie we wszystkich grupach wieku nastąpiło obniżenie częstości wydawania na świat dzieci pozamałżeńskich. Tak jednak się nie stało.

Tabela 3. Wiek a udział urodzeń pozamałżeńskich w latach 2016 i 2017 (jako \% ogółu urodzeń matek w danym wieku)

\begin{tabular}{|l|c|c|c|c|c|c|c|}
\hline \multirow{2}{*}{ Rok i region } & \multicolumn{7}{|c|}{ Wiek matki (w latach) } \\
\cline { 2 - 8 } & $15-19$ & $20-24$ & $25-29$ & $30-34$ & $35-39$ & $40-44$ & $45-49$ \\
\hline Polska & 85,0 & 48,6 & 20,0 & 16,4 & 19,7 & 25,2 & 25,6 \\
\hline Miasto & 89,7 & 57,6 & 23,5 & 18,7 & 22,8 & 29,6 & 32,0 \\
\hline Wieś & 79,7 & 40,1 & 15,4 & 12,3 & 13,9 & 17,8 & 14,4 \\
\hline \multicolumn{7}{|c|}{2017} \\
\hline Polska & 82,8 & 47,3 & 19,6 & 16,4 & 19,6 & 24,6 & 25,2 \\
\hline Miasto & 87,9 & 56,9 & 23,4 & 18,9 & 22,8 & 28,5 & 29,8 \\
\hline Wieś & 77,2 & 37,9 & 14,9 & 12,1 & 13,9 & 17,7 & 19,2 \\
\hline
\end{tabular}

Źródło: Obliczenia własne na podstawie bazy danych GUS Demografia.

Choć w wielu grupach wieku taki spadek nastąpił, to zazwyczaj był obserwowalny przed 30. rokiem życia, a dodatkowo w grupach, w których wystąpił, był zdecydowanie niższy niż ogólny zaobserwowany spadek udziału urodzeń pozamałżeńskich dla Polski. Dodatkowo, znaleźć można kilka przypadków utrzymania się wartości, a nawet w miastach z nieznacznym wzrostem badanej frakcji w wieku 30-34 lata (pomijam tu casus grupy wieku 45-49 na wsi z uwagi na niewielką liczbę urodzeń w tym wieku).

Wyjaśnienia doszukać się można przede wszystkim w określeniu związku pomiędzy wzrostem liczby urodzeń a poziomem płodności kobiet, rozkładem kobiet w wieku rozrodczym i rozkładem urodzeń według wieku matek. Czynnikami determinującymi zmiany był bowiem, z jednej strony, nierównomierny wzrost płodności w różnych grupach wieku (największy wzrost nastąpił w grupie 25-34 lata, a zatem w wieku o najniższej często- 
ści urodzeń pozamałżeńskich), z drugiej zaś czynnik kohortowy - fakt, iż wskutek zróżnicowanej liczby urodzeń w przeszłości mamy do czynienia ze znacznie różniącymi się liczebnościami potencjalnych matek w poszczególnych grupach wieku (wskutek przechodzenia przez tzw. drugi powojenny wyż demograficzny przez kolejne stadia wieku rozrodczego wzrasta udział kobiet w wieku 30-40 lat, a zatem ponownie w wieku relatywnie niskiej skłonności do wydawania na świat dzieci nieślubnych).

\section{Przestrzenne zróżnicowanie zmian zachowań rozrodczych ${ }^{8}$}

Współczesna Polska jest bardzo zróżnicowana, jeśli idzie o poziom dzietności, choć jednocześnie w praktyce zanikła obserwowana w całym powojennym okresie różnica poziomu tego współczynnika między ludnością miast i wsi. Owo zróżnicowanie wynika zarówno z rzeczywistych różnic zachowań prokreacyjnych, jak i odzwierciedla czynniki zakłócające pomiar poziom migracji oraz stopień zaawansowania zmiany kalendarza płodności. W przypadku migracji chodzi o nierównomierną skalę nierejestrowanego (a zatem nieuwzględnionego w badaniach GUS) odpływu młodej ludności z poszczególnych województw. Z kolei w przypadku kalendarza płodności chodzi o uwzględnienie różnego momentu i tempa zmian zachowań demograficznych w sferze rozrodczości, nie wszędzie bowiem w tym samym czasie rozpoczął się proces odraczania momentu wydawania na świat potomstwa (to właśnie najlepiej tłumaczy zanik różnic między miastem i wsią).

W efekcie oddziaływania powyższych czynników w trakcie ostatnich dwóch dekad można było zaobserwować stałe różnice poziomu dzietności w układzie województw (tab. 4).

\footnotetext{
${ }^{8} \mathrm{~W}$ niniejszym punkcie wykorzystuję zmodyfikowane i zaktualizowane fragmenty innego opracowania: P. Szukalski, Bliżej zastępowalności pokoleń. O przestrzennym zróżnicowaniu zmian poziomu dzietności w latach 2015-2017, „Demografia i Gerontologia Społeczna - Biuletyn Informacyjny" (2018) nr 4, 1-7; http://hdl.handle.net/11089/25096 (dostęp: 13.08.2018).
} 
Tabela 4. Współczynniki dzietności w województwach w latach 1995-2017

\begin{tabular}{|l|c|c|c|c|c|c|c|c|}
\hline Województwo & 1995 & 2000 & 2005 & 2010 & 2015 & \multicolumn{3}{|c|}{2017} \\
\cline { 6 - 9 } & & & & & & Ogółem & Miasto & Wieś \\
\hline Dolnośląskie & 1,863 & 1,467 & 1,210 & 1,143 & 1,207 & 1,361 & 1,324 & 1,431 \\
\hline $\begin{array}{l}\text { Kujawsko- } \\
\text {-pomorskie }\end{array}$ & 2,108 & 1,665 & 1,387 & 1,271 & 1,249 & 1,411 & 1,364 & 1,471 \\
\hline Lubelskie & 2,378 & 1,805 & 1,495 & 1,343 & 1,257 & 1,372 & 1,330 & 1,400 \\
\hline Lubuskie & 2,140 & 1,694 & 1,314 & 1,247 & 1,253 & 1,430 & 1,413 & 1,451 \\
\hline Łódzkie & 1,950 & 1,535 & 1,268 & 1,185 & 1,260 & 1,409 & 1,359 & 1,482 \\
\hline Małopolskie & 2,199 & 1,710 & 1,476 & 1,272 & 1,320 & 1,486 & 1,433 & 1,518 \\
\hline Mazowieckie & 1,999 & 1,593 & 1,327 & 1,253 & 1,409 & 1,570 & 1,538 & 1,595 \\
\hline Opolskie & 1,869 & 1,385 & 1,166 & 1,044 & 1,124 & 1,288 & 1,313 & 1,260 \\
\hline Podkarpackie & 2,456 & 1,809 & 1,538 & 1,288 & 1,199 & 1,372 & 1,288 & 1,423 \\
\hline Podlaskie & 2,381 & 1,786 & 1,420 & 1,257 & 1,226 & 1,401 & 1,419 & 1,358 \\
\hline Pomorskie & 2,117 & 1,668 & 1,426 & 1,352 & 1,412 & 1,626 & 1,526 & 1,761 \\
\hline Śląskie & 1,725 & 1,402 & 1,197 & 1,129 & 1,258 & 1,424 & 1,416 & 1,450 \\
\hline Świętokrzyskie & 2,362 & 1,755 & 1,404 & 1,239 & 1,181 & 1,258 & 1,170 & 1,316 \\
\hline $\begin{array}{l}\text { Warmińsko- } \\
\text {-mazurskie }\end{array}$ & 2,302 & 1,753 & 1,455 & 1,346 & 1,228 & 1,412 & 1,389 & 1,433 \\
\hline Wielkopolskie & 2,167 & 1,684 & 1,395 & 1,311 & 1,384 & 1,579 & 1,509 & 1,655 \\
\hline $\begin{array}{l}\text { Zachodniopo- } \\
\text { morskie }\end{array}$ & 2,057 & 1,630 & 1,320 & 1,228 & 1,218 & 1,372 & 1,354 & 1,397 \\
\hline Polska & $\mathbf{2 , 0 4 9}$ & $\mathbf{1 , 6 1 1}$ & $\mathbf{1 , 3 3 7}$ & $\mathbf{1 , 2 4 0}$ & $\mathbf{1 , 2 8 9}$ & $\mathbf{1 , 4 5 3}$ & $\mathbf{1 , 4 1 8}$ & $\mathbf{1 , 4 9 3}$ \\
\hline
\end{tabular}

Źródło: Roczniki Demograficzne GUS oraz baza danych GUS Demografia.

Jak łatwo się domyślać, w niniejszym opracowaniu będzie nas interesować głównie to, czy i w jakim stopniu województwa reagowały na bodźce płynące w ostatnich dwóch latach ze sfery polityki społecznej oraz z poprawy sytuacji na rynku pracy, zwiększające skłonność do posiadania potomstwa. Wspomniana wcześniej odmienna trajektoria zmian odpowiada nie tylko za występujące zróżnicowanie, ale również za to, iż w latach 2016 i 2017 najwyższy wzrost współczynnika dzietności nie został odnotowany tam, gdzie należałoby tego oczekiwać. Wydaje się sensowne, iż wzrost ten powinien być najwyższy w tych regionach, gdzie - z jednej strony - wystę- 
pował tradycyjnie wysoki poziom dzietności (dodatkowy strumień środków z programu Rodzina 500+ oraz poprawa sytuacji na rynku pracy powinny umożliwić realizację planów prokreacyjnych), z drugiej zaś strony, gdzie płace nominalne są najniższe (a zatem np. świadczenie $500 \mathrm{zł}$ posiada realnie wyższą wartość z uwagi na nie tylko niższe od ogólnopolskiej średniej płace, ale i dostosowany do nich poziom cen). Tymczasem zamiast spodziewanego wzrostu w województwach Polski Wschodniej, w najwyższym stopniu dzietność wzrosła w województwach o relatywnie dobrej sytuacji $\mathrm{w}$ sferze prokreacji i generalnie w miarę dobrej sytuacji gospodarczej definiowanej w kategoriach PKB per capita (pomorskie i wielkopolskie) albo w województwach zlokalizowanych na terenie Ziem Odzyskanych (warmińsko-mazurskie i lubuskie) (tab. 5).

Tabela 5.Przyrosty współczynnika dzietności w latach 2015-2017 według województw

\begin{tabular}{|l|c|c|c|c|c|c|}
\hline \multirow{2}{*}{ Województwo } & \multicolumn{3}{|c|}{ Przyrosty bezwzględne } & \multicolumn{3}{c|}{ Przyrosty względne (w \%) } \\
\cline { 2 - 7 } & Ogółem & Miasto & Wieś & Ogółem & Miasto & Wieś \\
\hline Dolnośląskie & 0,155 & 0,148 & 0,166 & 12,8 & 12,6 & 13,2 \\
\hline Kujawsko-pomorskie & 0,162 & 0,169 & 0,154 & 13,0 & 14,2 & 11,7 \\
\hline Lubelskie & 0,116 & 0,097 & 0,132 & 9,2 & 7,9 & 10,4 \\
\hline Lubuskie & 0,177 & 0,174 & 0,183 & 14,1 & 14,1 & 14,4 \\
\hline Łódzkie & 0,149 & 0,156 & 0,136 & 11,8 & 13,0 & 10,1 \\
\hline Małopolskie & 0,166 & 0,205 & 0,123 & 12,6 & 16,7 & 8,8 \\
\hline Mazowieckie & 0,161 & 0,175 & 0,140 & 11,4 & 12,9 & 9,6 \\
\hline Opolskie & 0,164 & 0,171 & 0,157 & 14,6 & 15,0 & 14,2 \\
\hline Podkarpackie & 0,173 & 0,167 & 0,177 & 14,5 & 14,9 & 14,2 \\
\hline Podlaskie & 0,175 & 0,235 & 0,070 & 14,3 & 19,9 & 5,4 \\
\hline Pomorskie & 0,213 & 0,194 & 0,234 & 15,1 & 14,6 & 15,3 \\
\hline Śląskie & 0,166 & 0,176 & 0,129 & 13,2 & 14,2 & 9,7 \\
\hline Świętokrzyskie & 0,077 & 0,078 & 0,074 & 6,5 & 7,1 & 6,0 \\
\hline Warmińsko-mazurskie & 0,184 & 0,244 & 0,104 & 14,9 & 21,3 & 7,8 \\
\hline Wielkopolskie & 0,195 & 0,218 & 0,169 & 14,1 & 16,9 & 11,3 \\
\hline Zachodniopomorskie & 0,154 & 0,192 & 0,086 & 12,7 & 16,5 & 6,6 \\
\hline Polska & $\mathbf{0 , 1 6 4}$ & $\mathbf{0 , 1 7 8}$ & $\mathbf{0 , 1 4 4}$ & $\mathbf{1 2 , 7}$ & $\mathbf{1 4 , 3}$ & $\mathbf{1 0 , 6}$ \\
\hline
\end{tabular}

Źródło: Obliczenia własne na podstawie bazy danych GUS Demografia.

Zastanawia bardzo słaba reakcja mieszkańców Lubelszczyzny i Kielecczyzny, tam bowiem zmiany miały najmniej widoczny charakter. Jednocze- 
śnie trzeba zaznaczyć, że silniejsze wzrosty widoczne były wśród ludności miast - nieliczne było grono województw, gdzie na wsi uzyskano wyższe przyrosty ( 5 regionów w przypadku zmian bezwzględnych i 4 w przypadku zmian względnych).

Również województwa są wewnętrznie bardzo zróżnicowane przestrzennie, jeśli idzie o poziom dzietności ${ }^{9}$.W przypadku badania powiatów trzeba jednak zdawać sobie sprawę z tego, iż w większości te jednostki administracyjne są relatywnie nieduże (większość powiatów ma bowiem do 60 tys. ludności), a zatem w przypadku badania zachowań rozrodczych podatne na zniekształcenia wynikające z relatywnie niskiej liczby urodzeń. $\mathrm{Z}$ tego wynikają obserwowane tam często duże i różnokierunkowe zmiany współczynników dzietności z roku na rok.

Tradycyjnie najniższą dzietnością charakteryzowały się najbardziej zurbanizowane powiaty położone w centrum regionu, zwłaszcza powiaty grodzkie. Z kolei najwyższym poziomem dzietności odznaczały się peryferyjnie położone powiaty o wysokim udziale ludności wiejskiej. Te zależności w ostatnich latach uległy pewnej modyfikacji, głównie wskutek widocznej w wielu dużych miastach zwyżki płodności, jak i tego, iż we wschodniej części Polski ludność wsi doświadcza głębokiej zmiany wzorca dzietności.

Międzyregionalne różnice w zakresie poziomu dzietności, a przede wszystkim tempa jej zmian, są znakomicie widoczne, gdy przeanalizujemy to, kiedy na terenie danego województwa odnotowano w powiatach najniższe poziomy dzietności (tab. 6).

\footnotetext{
${ }^{9}$ P. Szukalski, Bliżej zastępowalności pokoleń. O przestrzennym zróżnicowaniu zmian poziomu dzietności w latach 2015-2017, „Demografia i Gerontologia Społeczna - Biuletyn Informacyjny" (2018) nr 4, 1-7; http://hdl.handle.net/11089/25096 (dostęp: 13.08.2018).
} 
Tabela 6. Liczba powiatów, w których odnotowano najniższy poziom dzietnościw latach 2002-2017 według województw ${ }^{10}$

\begin{tabular}{|c|c|c|c|c|c|c|c|c|c|c|c|c|c|c|c|c|}
\hline Województwo & 용 & ֻి & ঠ্ণ & 옹 & ঠ্ণ & 용 & $\stackrel{\infty}{\stackrel{\Upsilon}{ి}}$ & ஓे & $\stackrel{\circ}{\stackrel{0}{\circ}}$ & ‡ె & 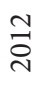 & $\stackrel{n}{\stackrel{n}{2}}$ & $\stackrel{+}{\stackrel{一}{\circ}}$ & 능 & $\stackrel{6}{\circ}$ & $\frac{1}{\circ}$ \\
\hline Dolnośląskie & 2 & 12 & 2 & 1 & - & - & - & - & - & - & - & 8 & 1 & - & 4 & - \\
\hline $\begin{array}{l}\text { Kujawsko- } \\
\text {-pomorskie }\end{array}$ & - & 1 & 1 & 4 & 2 & - & - & - & - & - & 1 & 3 & 2 & 5 & 3 & 1 \\
\hline Lubelskie & 1 & - & 2 & - & 1 & - & - & - & - & 1 & - & 6 & 5 & 7 & 1 & - \\
\hline Lubuskie & 3 & 4 & - & 1 & - & - & - & - & - & - & - & 1 & - & 4 & 1 & - \\
\hline Łódzkie & 4 & 6 & 3 & 3 & - & - & - & 1 & - & - & 1 & - & 1 & 4 & 1 & - \\
\hline Małopolskie & 1 & 3 & 1 & 1 & 3 & - & 1 & - & - & - & - & 4 & 2 & 6 & - & - \\
\hline Mazowieckie & 7 & 4 & 4 & 4 & - & - & - & - & - & - & 4 & 4 & 4 & 9 & 1 & - \\
\hline Opolskie & 1 & 4 & 4 & - & - & - & - & - & - & - & - & 1 & - & 2 & - & - \\
\hline Podkarpackie & - & 1 & 1 & - & 2 & - & 1 & - & - & 1 & - & 2 & 5 & 10 & 3 & - \\
\hline Podlaskie & - & 1 & - & 1 & 1 & - & - & - & - & 1 & 1 & 7 & 1 & 3 & 1 & - \\
\hline Pomorskie & 5 & 1 & 1 & 2 & - & - & - & - & - & - & - & 6 & - & 4 & 1 & - \\
\hline Śląskie & 7 & 16 & 4 & 5 & 3 & - & - & - & - & - & - & 1 & - & - & - & - \\
\hline Świętokrzyskie & - & - & 1 & 1 & 1 & - & 2 & - & - & - & - & 3 & 3 & 2 & 1 & 1 \\
\hline $\begin{array}{l}\text { Warmińsko-Ma- } \\
\text { zurskie }\end{array}$ & - & 1 & - & 1 & - & - & - & - & - & - & 1 & 6 & 2 & 8 & 2 & - \\
\hline Wielkopolskie & 6 & 5 & 12 & 2 & - & - & - & - & - & 1 & 2 & 2 & 2 & 2 & 1 & - \\
\hline $\begin{array}{l}\text { Zachodniopomor- } \\
\text { skie }\end{array}$ & 2 & 4 & - & 1 & - & - & - & - & - & 2 & 2 & 2 & 2 & 5 & 1 & - \\
\hline Polska & 39 & 63 & 36 & 27 & 13 & $\mathbf{0}$ & 4 & 1 & 0 & 6 & 12 & 56 & 30 & 71 & 21 & 2 \\
\hline
\end{tabular}

Źródło: Opracowanie własne na podstawie bazy danych GUS Demografia.

Powyższe dane jednoznacznie wskazują na różnice pomiędzy Polską Zachodnią i Wschodnią, a na dodatek między terenami silniej i słabiej zurbanizowanymi. Tak się bowiem składa, iż - niezależnie od położenia danego województwa - w pierwszej kolejności minimalny poziom dzietności

\footnotetext{
${ }^{10} \mathrm{Z}$ uwagi na dwukrotne powtarzanie się tych samych wartości w przypadku dwóch powiatów łączna suma powiatów jest powiększona o owe dwa - są to odpowiednio powiat rzeszowski (woj. podkarpackie) i buski (świętokrzyskie); w obu przypadkach wartości współczynnika dzietności dublowały się w latach 2006 i 2008.
} 
odnotowywany jest wśród ludności powiatów grodzkich i silnie zurbanizowanych, zaś w ostatniej kolejności w peryferyjnych powiatach o wysokim odsetku ludności wiejskiej.

Wspomniana powyżej logika zmian (tab. 6) w znacznym stopniu determinuje dzisiejszą pozycję województw i powiatów, jeśli idzie o poziom dzietności, wskazując, kiedy nastąpił poziom minimalny i od jak dawna następuje odbudowa płodności. Drugim elementem silnie oddziałującym na dzisiejszą sytuację jest „dzieciolubność”, tradycyjny poziom dzietności przejawiający większe lub mniejsze przywiązanie do tradycyjnego modelu rodziny i wzorca płodności, charakteryzującego się również i większą liczbą wydawanego na świat potomstwa. Oba te czynniki - wraz ze wspomnianym wpływem migracji - wpływają na to, iż w ramach regionów i między nimi występuje olbrzymie zróżnicowanie najwyższych i najniższych poziomów dzietności odnotowywanych w powiatach ${ }^{11}$. Choć jedynie w przypadku województwa świętokrzyskiego powiat o najwyższej dzietności odznacza się wartością niższą od średniej krajowej, to w opolskim i zachodniopomorskim wartości te są wyższe jedynie nieznacznie.

\section{Podsumowanie}

Celem niniejszego opracowania była próba interpretacji zachodzących w latach 2016-2017 przemian w sferze prokreacji z perspektywy ich zgodności z oczekiwaniami odnośnie do wpływu programu rządowego Rodzina $500+$ na wzrost liczby urodzeń. Dokonany tu przegląd wskazuje, iż uzyskane efekty w zakresie wzrostu liczby urodzeń znacznie przekroczyły zakładane rezultaty, choć potencjał wzrostu ujawnił się już w okresie poprzedzającym wdrożenie rządowego programu. Zgodnie z oczekiwaniami największa skala zmian wystąpiła wśród kobiet w środkowej części wieku rozrodczego, zaś odnosiły się one przede wszystkim do urodzeń drugich i trzecich. Całkowicie inne oczekiwania od faktycznych zmian możnaby natomiast sformułować w przypadku różniczachowań reprodukcyjnych w przestrzeni. To nie województwa o najniższym poziomie rozwoju ekonomicznego i naj-

${ }^{11}$ P. Szukalski, Bliżej zastępowalności pokoleń. O przestrzennym zróżnicowaniu zmian poziomu dzietności w latach 2015-2017, „Demografia i Gerontologia Społeczna - Biuletyn Informacyjny" (2018) nr 4, 1-7;http://hdl.handle.net/11089/25096 (dostęp: 13.08.2018). 
niższych płacach - gdzie wartość 500 zł jest relatywnie największa - charakteryzowały się największymi zmianami. W tym przypadku należy sobie zdawać sprawę z tego, że poszczególne regiony Polski odznaczają się bardzo zróżnicowaną ścieżką przemian w sferze życia rodzinnego, stąd też kilka województw o najniższym poziomie rozwoju jest równocześnie miejscami, gdzie zmiany modelu rodziny zaczęly się upowszechniać z opóźnieniem, ale - skoro zostały uruchomione - są one odporne na działanie bodźców zewnętrznych.

Program Rodzina 500+ w świetle przedstawionych w niniejszym opracowaniu danych nie zmienił demograficznej rzeczywistości, a co najwyżej wzmocnił obserwowane od 2014 roku tendencje. Przekaz płynący z tego i innych rządowych programów (przede wszystkich odnoszących się do zapewnienia opieki nad małym dzieckiem), mówiący o wadze, jaką rodzina, macierzyństwo i rodzicielstwo majądla władz publicznych, może zaprocentować w przyszłości, gdy potencjalni rodzice będą bardziej skłonni do posiadania potomstwa, wiedząc, że przynajmniej część kosztów związanych $\mathrm{z}$ jego wychowaniem zostanie przejęta przez państwo i społeczeństwo.

\section{Bibliografia}

CBOS (Centrum Badania Opinii Publicznej),Ocena programu „Rodzina 500 plus" po blisko roku od jego wprowadzenia, Komunikat z badań nr 36 (2017); http://www.cbos.pl/SPISKOM.POL/2017/K_036_17.PDF (13.08.2018).

Duszczyk M., Lesińska M., Upolitycznienie procesów demograficznych - próba podejścia teoretycznego, „Problemy Polityki Społecznej” (2016) 3(34), s. 13-25; http://www.problemypolitykispolecznej.pl/images/czasopisma/PELNE/PPSSiD34.pdf (13.08.2018).

Gołata E., Estimation of fertility in Poland and of Polish born women in the United Kingdom, „Studia Demograficzne”(2016) nr 1 (169), s. 13-38; http://sd.czasopisma.pan.pl/images/data/sd/wydania/no_1_169_2016/ SD_1-2016_3_GOLATA.pdf(13.08.2018). 
Gromada A., 2016, Rodzina 500+ jako polityka publiczna; http://krytykapolityczna.pl/file/2016/02/gromada_rodzina_500.pdf (13.08.2018).

Kotowska I. (red.), Niska dzietność w Polsce w kontekście percepcji Polaków. Diagnoza społeczna 2013, Warszawa 2014; http://www.diagnoza.com/ pliki/raporty_tematyczne/Niska_dzietnosc_w_Polsce.pdf (13.08.2018).

Puślecki D., Polityka wsparcia rodziny czy stymulowanie wzrostu demograficznego w Programie Rodzina 500 plus, „Przegląd Politologiczny”(2016) nr 3, s. 79-91; http://pressto.amu.edu.pl/index.php/pp/article/viewFile/7203/7230 (13.08.2018).

RRL (Rządowa Rada Ludnościowa), Sytuacja demograficzna Polski. Raport 2016-2017, ZWS GUS, Warszawa 2017, s. 240; http://bip.stat.gov.pl/organizacja-statystyki-publicznej/rzadowa-rada-ludnosciowa/publikacje-rzadowej-rady-ludnosciowej/ (13.08.2018).

Szukalski P., Bliżej zastępowalności pokoleń. O przestrzennym zróżnicowaniu zmian poziomu dzietności w latach 2015-2017, „Demografia i Gerontologia Społeczna - Biuletyn Informacyjny" (2018) nr 4, 1-7; http://hdl. handle.net/11089/25096 (13.08.2018).

Szukalski P., Dlaczego w 2017 r. nastąpił spadek udziału urodzeń pozamałżeńskich?, „Demografia i Gerontologia Społeczna - Biuletyn Informacyjny” (2018) nr 5, s. 1-7; http://hdl.handle.net/11089/25395 (13.08.2018).

Szukalski P., Przestrzenne zróżnicowanie dzietności w Polsce, „Wiadomości Statystyczne" (2015), nr 4, s. 13-27; http://hdl.handle.net/11089/8118 (13.08.2018).

Szukalski P., Urodzenia pozamałżeńskie w Polsce przełomu XX i XXI wieku, „Wiadomości Statystyczne” (2010) nr 2, s. 38-52; http://dspace.uni.lodz. pl:8080/xmlui/handle/11089/3636 (13.08.2018).

Szukalski P., Wielodzietność we współczesnej Polsce w świetle statystyk urodzeń, „Demografia i Gerontologia Społeczna - Biuletyn Informacyjny” (2018) nr 3, s. 1-6; http://hdl.handle.net/11089/24923 (13.08.2018). 